\title{
浅析电力营销服务中的业扩报装工作问题及其措施
}

\author{
谈艳
}

国网赣西供电公司

DOI:10.32629/hwr.v2i12.1725

[摘 要] 电力营销服务中的业扩报装工作就是受理用户新装、增容用电的申请书、审批用电申请资料、确定供电方案、办 理用电工程的设计、施工、验收、签订供用电合同,直至装表接电的全过程,总称业扩报装服务,也称为报装接电工作。随着社 会经济的发展以及工业化程度的不断提高,使得业扩报装工作日益增加,同时基于各种因素的影响,使其存在诸多问题,基于此, 本文阐述了电力营销服务中的业扩报装工作的重要性, 对电力营销服务中的业扩报装工作问题及其措施进行了探讨分析, 旨在 提高供电公司的社会效益与经济效益。

[关键词] 电力营销服务; 业扩报装工作; 重要性; 问题; 措施

依据国家投资规定, 国家只负责发电及其相应的输变电 设施部分投资, 其余一般依靠电力业扩供电工程贴费等集资 办电来解决, 也就是靠用户投资来解决。因此电力其余各部 门必须把业扩报装工作当做一个长期性、经常性的重要任务 来抓, 这也是提高电力公司自身经济效益和社会经济效益的 要求。所以要求必须正确理解和执行电力营销服务中的业扩 报装工作方针政策, 积极完成业扩报装服务任务, 努力做好 优质服务。以下就电力营销服务中的业扩报装工作问题及其 措施进行了探讨分析。

\section{1 电力营销服务中的业扩报装工作重要性分析}

电力营销服务中的业扩报装工作是供电公司运营过程 中的重要内容, 直接关系到供电公司的整体运营质量和效益, 因此供电公司需要加强对业扩报装工作进行管理, 为用户提 供更加优质的服务。业扩报装服务是电力发展的关键环节, 其主要包括受理用电申请、现场勘查、确定供电方案、审查 供电工程设计单位的资质和供电设计图纸以及施工单位的 资质、检查供电施工过程、竣工验收、签订用电供电合同、 安装电表等环节。根据电力部门的规定, 任何一个新用户和 原用户的新装、增容用电, 都要到供电公司营销部门办理用 电申请。电力公司业扩报装服务是电力公司与用电客户建立 起的供电关系, 主要是用电客户为了向电力公司申请到安全 用电, 同电力公司所建立的合作关系, 这种申请与批准的业 务流程就是业扩报装服务的主要工作。电力营销中的大部分 数据来自业务扩报装部门数据, 这个部门会对客户的信息进 行相应分析和总结, 并把信息进行相应的整理, 然后上传, 从 而实现企业内部所有部门的资源共享。业扩报装工作是客户 通过电力公司接触并建立初步关系的重要的一个平台, 是电 力公司的一个形象平台。这个平台的运行良好与否, 不仅会 影响电力营销管理的整体运行的效率和其运行质量, 也会对 电力公司的整体形象和服务质量产生一定影响。

\section{2 电力营销服务中的业扩报装工作问题分析}

电力营销服务中的业扩报装工作存在的问题主要有: (1) 电力设备采购及合同签订问题分析。供电合同有效提高了供
电关系的法律约束力, 但在实际使用中, 合同的法律约束力 却受到各种因素的影响和限制。客户为获取最大利益, 采取 诸多非法手段, 甚至贿赂电力公司工作人员, 无视电力公司 相关的管理规定; 而企业的工作人员缺乏必要的责任意识, 收取好处后无视电力公司对设备采购相关内容的规定, 在设 备采购环节以权谋私, 不重视设备质量, 而是为个人利益采 取低买高报的方法赚取差价, 严重影响了供电设备的安全性 和运行的稳定性。(2) 材料质量问题。随着社会用电的总体 需求量逐年上升, 电力公司的数量和规模也随之扩大, 客观 上加剧了电力公司之间的市场竞争。出于成本费用的考虑, 部分施工单位在进行工程安装施工时, 使用廉价、劣质的材 料设备, 损害了项目工程的总体质量, 无形中加大了供电项 目的安全隐患。此外, 电力公司在对工程进行验收时, 部分人 员并没有严格按照规章制度对工程的各个环节严格把关, 未 能有效开展工程质量监督, 影响了供电项目的整体安全性。 (3) 客户进行用电申请时的违规问题。客户用电申请阶段中, 客户方多以自身利益最大化和成本最低为基本出发, 而采取 各种非常规渠道和流程来最大限度减少自身费用支出。一般 通过人脉关系, 尽可能绕开现有规章制度的限制进行违规操 作, 最后给电力公司正常的营销造成不利影响, 严重损害企 业的经济利益和健康发展。(4) 签订合同和安装电表阶段存 在的问题。电力公司与用电客户在签订合同时, 电力用户为 了减少供电项目施工成本, 会收买电企员工, 电企员工没有 按照业扩报装服务管理制度进行工作, 没有严格验收电表, 无法确保电表质量和性能, 造成供电过程中电能损耗较大。 同时, 由于电力设备生产厂家较多, 同样型号和规格的产生 质量差异较大, 价格也不尽相同, 采购设备时部分采购人员 存在以权谋私的违规行为。由于合同双方意见不一致, 没有 进行有效的沟通协调, 导致签订过程缓慢, 延长了业扩报装 服务施工耗时, 无法满足客户的正常需求。

\section{3 电力营销服务中的业扩报装工作措施}

3.1 健全完善客户经理责任制度。电力公司各个部门都 要提高客户服务意识, 由客户经理对图纸审查、现场勘查、 
竣工验收、签订供电用电合同、送电服务等负责, 确保供电 项目的施工进度和效率, 按照明确的服务条款进行监督和管 理工作, 并负责对业扩报装工作人员的考核和评价。要树立 以客户为中心的工作理念, 建立以业扩报装工作为核心的工 作体系, 实行客户经理责任制, 建立健全业扩报装工作管理 制度, 为重要的电力用户提供优质服务, 从而提高客户的满 意度和企业的影响力。

3.2 加强业扩工程的现代化管理, 建立起专门针对业扩 工程的进度管理跟踪系统, 以此加强工程管理中涉及到供电 公司各部门间的服协同能力。业扩项目经理对大客户的相关 工程信息进行准确掌握, 在业扩工程管理过程中使用及时的 跟踪系统进行部门间的交流, 在之前一个部门的工作完成后 通过系统传送到与之相关的下一个部门中, 此时, 下一个部 门中的负责人根据规定流程要求执行相应的操作。在业扩工 程项目中, 业扩项目经理是其中主要的负责人, 采用这种形 式能够对工程的各项进度进行实时地监控, 如果其中的任何 一个部门没有按时完成任务, 系统就会进行自动提醒

3.3 严格业扩报装服务的监督管理。具体表现为: (1) 加强供电设备质量的监督管理。供电项目的设备质量和施工 质量, 决定了项目的整体质量。在送点环节严格控制和把关, 是做好供电工作的基本要求, 除了要确保供电方案以及设计 图纸, 符合标准之外, 更要在审核意见验收过程中, 保证真 实、有效的管理和监察, 并且根据业扩报装服务的要求来具 体组织送点过程。（2）加强受理环节的监督管理。业扩报装 服务受理人员要根据国家发改委、国家电网和相关行业规定, 尤其是在受理重要电力客户的报装过程中, 对客户的负荷等 级、设备清单、可靠性要求等书面材料进行详细检查, 根据 相关规定对立项批文进行审核, 并检查客户是否具备安全生 产许可证、营销许可证和环保审批等。(3) 加强供电图纸的 监督管理。根据国家规定和行业规范审查设计图纸, 不得私 自降低供电标准。因为设计图纸中的安全隐患不仅会降低施 工效率和质量, 还会造成安全事故。虽然施工现场存在的问 题包括违章操作等, 但是设计图纸是施工的前提和基础, 其 安全隐患会导致日后施工出现问题。(4) 加强用电供电合同
协商和签订过程的监督管理。供电用电合同是客户和电力公 司之间发生联系的法律文件, 是控制和约束双方行为的重要 依据, 也是确保双方权益的纽带, 加强对合同的管理, 在签订 之前进行充分的沟通和交流, 对合同进行严格审查, 能够从 根本上规避业扩报装工作中的风险, 减少了双方的纠纷和损 失, 有利于维护双方合法权益。

3.4 建立健全例会制度以及考核机制。基于此电力营销 服务中的业扩报装工作属于多环节工作，必须整合各项工作 的进度和资源, 既要保证工作安全, 又必须使客户用电满意, 所以电力公司应该与客户建立起对应的例会制度。定期跟踪 客户的用电行为习惯, 将送电方式不断改进, 直到客户满意 为止。并且需要针对性地提出具有可操作性的合理意见, 帮 助客户升级用电方式。

\section{4 结束语}

综上所述, 随着国家电网体制改革的不断深入, 促进了 电力企业的进步。同时为了促进电力公司的可持续发展, 需 要做好电力营销服务中的业扩报装工作, 建立完善的工作责 任制和客户沟通联系机制, 这样才有利于提高电力公司的业 务水平和服务质量。因此为了保障电力营销服务中的业扩报 装工作有效性, 必须加强对对电力营销服务中的业扩报装工 作问题及其措施进行分析。

[参考文献]

[1]杜杰.探讨电力营销业扩报装的问题与应对策略 [J]. 企业文化,2016(11):74.

[2]戴抒言.试论电力营销业扩报装的问题及对策[J].中 国经贸,2016(18):36.

[3]戴向东.电力大客户业扩工程项目管理分析[J].科技 资讯,2017(10):31.

[4]龚思如.关于电力营销业扩报装流程规范化管理分析 [J].化工管理,2017(02):40,

[5]周莉.关于电力营销业扩报装的问题分析及对策探讨 [J].中国高新区,2017(04):44。

[6]邱添. 电力营销业扩报装的问题及有效对策研究 [J]. 计算机产品与流通,2017(07):75. 